\title{
Emotional preparation for the unification of Korea: Through the embracement, forgiveness and love shown in the Gospel of Matthew
}

\begin{tabular}{|c|c|}
\hline \multicolumn{2}{|c|}{$\begin{array}{l}\text { Author: } \\
\text { In-Cheol Shin } 1,2\end{array}$} \\
\hline \multicolumn{2}{|c|}{$\begin{array}{l}\text { Affiliations: } \\
{ }^{1} \text { Korea Baptist Theological } \\
\text { University and Seminary, } \\
\text { Daejeon, Korea }\end{array}$} \\
\hline \multicolumn{2}{|c|}{$\begin{array}{l}{ }^{2} \text { Department of New Testament } \\
\text { Studies, Faculty of Theology } \\
\text { and Religion, University of } \\
\text { Pretoria, Pretoria, South Africa }\end{array}$} \\
\hline \multicolumn{2}{|c|}{$\begin{array}{l}\text { Research Project Registration: } \\
\text { Project Leader: A.G. van Aarde } \\
\text { Project Number: } 2334682\end{array}$} \\
\hline \multicolumn{2}{|c|}{$\begin{array}{l}\text { This research is part of the } \\
\text { research project, 'Biblical } \\
\text { Theology and Hermeneutics', } \\
\text { directed by Prof. Dr Andries } \\
\text { van Aarde, Post Retirement } \\
\text { Professor and Senior Research } \\
\text { Fellow in the Dean's Office, } \\
\text { Faculty of Theology and } \\
\text { Religion, University of Pretoria. }\end{array}$} \\
\hline \multicolumn{2}{|c|}{$\begin{array}{l}\text { Corresponding author: } \\
\text { In-Cheol Shin, } \\
\text { incheolshin@kbtus.ac.kr }\end{array}$} \\
\hline $\begin{array}{l}\text { Dates: } \\
\text { Received: } 25 \\
\text { Accepted: } 02 \\
\text { Published: } 07\end{array}$ & $\begin{array}{l}\text { une } 2020 \\
\text { Sept. } 2020 \\
\text { Dec. } 2020\end{array}$ \\
\hline \multicolumn{2}{|c|}{$\begin{array}{l}\text { How to cite this article: } \\
\text { Shin, I-C., 2020, } \\
\text { 'Emotional preparation for the } \\
\text { unification of Korea: Through } \\
\text { the embracement, forgiveness } \\
\text { and love shown in the Gospel } \\
\text { of Matthew', HTS Teologiese } \\
\text { Studies/Theological Studies } \\
76(3), \text { a6217. https://doi.org/ } \\
\text { 10.4102/hts.v76i3.6217 }\end{array}$} \\
\hline \multicolumn{2}{|c|}{$\begin{array}{l}\text { (c) 2020. The Authors } \\
\text { Licensee: AOSIS. This } \\
\text { is licensed under the } \\
\text { Creative Commons } \\
\text { Attribution License. }\end{array}$} \\
\hline Read online: & \\
\hline 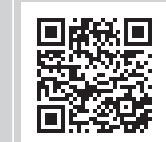 & $\begin{array}{l}\text { Scan this QR } \\
\text { code with your } \\
\text { smart phone or } \\
\text { mobile device } \\
\text { to read online. }\end{array}$ \\
\hline
\end{tabular}

The greatest wish of the Baeda 1 people, or South Koreans, living in the Korean Peninsula is the unification of Korea. However, even when it has been 70 years since the outbreak of the Korean War, the two Koreas that used to be one nation are still in conflict. There have been many discourses on unification over the past 70 years, but these discourses still fail to create clear rules and a framework for unification. Discourses from the perspective of biblical theology offer insight regarding the problems at stake as well as alternatives, but they do not offer perspectives on a definite solution. This article, in line with its statement on biblical theology, does not pretend to contribute to a clearcut solution to meet the challenge of Korea's unification. Rather, this article intends to contribute to the formation of an emotional consensus that can contribute to the unification of Korea by looking at the teachings about peace in the Gospel of Matthew. The article explores whether the notion of embracement, forgiveness and love written during the conflict between the Matthean community and Formative Judaism can be applied to help create an emotional bond between the two Koreas. The terms embracement, forgiveness and love found in the Gospel of Matthew are upheld as symbolising peace derived from opposition and conflict. Jesus taught us to overcome situations of opposition and conflict through embracement, forgiveness and love.

Contribution: The purpose and contribution of this article was to discuss if the notions of embracement, forgiveness and love found in the Gospel of Matthew can be helpful for the emotional preparation of the peaceful unification of the Korean Peninsula by comparing the situations reflected in the Gospel of Matthew and that of the Korean Peninsula.

Keywords: Korean War; emotional preparation; unification of Korea; embracement; forgiveness; love; Gospel of Matthew.

\section{Introduction}

This year marks the 70th year of the Korean War during which the two Koreas, respectively, symbolising democracy and communism, suffered the bleeding of their own people. During the past 70 years, both South and North Korea inflicted damage and deep pain upon each other that would be hard to forgive because of constant conflicts (cf. Volf 2000a:100). Although the Korean Church has made various efforts for the reunification of Korea, the long-term severance of the two countries has led to the amplification of emotional difference between the two countries. At this point in time, even the national identity is blurred and the Korean Church finds itself under severe pressure to give hope to the people who are longing for unification. In short, the Korean Church finds itself at the point where it has to propose a definite alternative for working towards the unification of the Korean Peninsula. Even though there are plenty of theological propositions on the unification of the Korean Peninsula, (Ahn 2017:198-222; Baik 2016:132-162), the Korean Church is challenged to provide a connection point that can bring the people of the two Koreas together on an emotional level. It is important to do so because unification is not merely an integration of territory, but also an amalgamation of the ideas and emotions of the two peoples. In other words, unification from a Christian point of view is to provide the basis for emotional, ideological and psychological homogeneity for the two peoples of Korea in order to communicate (see Volf 2000b:159).

Although various articles on the subject of unification on the Korean Peninsula have been published, it remains rather difficult to discuss the unification of the Korean Peninsula from a biblical perspective (Lee 2012:143-161; Park 2012:27-37). This is because the political and social background of the divided Korean Peninsula differs substantially from the background of the Bible (Woo 2018:16-20). At the same time, there is no need to unconditionally approve or neglect the search for answers to the unification discourse on the Korean Peninsula in the Bible. 
There is no basis that the Christian Bible can provide for a complete solution nor can it contribute to the unification of the Korean Peninsula. The biblical discourse amongst Christian scholars on unification until now has mainly focussed on resolving the conflict of the South and North (Hur 2010; Jeon 2014; Joo 2015). However, there is now the need for a more comprehensive, biblical contribution to the unification of the Korean Peninsula. This is because the study of unification by biblical theologians is an essential asset for the future unification of Korea and a valuable and useful academic achievement. Moreover, there are not many articles in the field of New Testament Studies dealing with the unification of the Korean Peninsula and the topic of unification is not receiving attention as an international research topic (Park 1995:172-203; Woo 2018:7-33).

This article aims to explore aspects of the discourse on unification in the first book of the New Testament, the Gospel of Matthew, and how it can contribute to the debate on the unification of the Korean Peninsula. The discourse on unification that will be dealt with in this article focusses on the ideas of pacifism ${ }^{1}$ found in the Gospel of Matthew (Shin 2012:91-117; Sim 2011:1-6). If the people of North and South Korea accept the idea of pacifism suggested by the Gospel of Matthew as the basis of their lives, unification of the emotional aspect can become a more visible or tangible achievement. Emotional reunification is important because even if you try to set the flag of unification in any physical way, you cannot achieve true unification unless you are emotionally prepared for it. Therefore, emotional unification is a psychological preparation in which the South and the North can begin to engage in peaceful exchange with each other. The basis for finding the principle of peaceful unification of the Korean Peninsula in the Gospel of Matthew is because the teachings of confrontation and reconciliation coexist in the text of Matthew (Neville 2007:131-161; Sim 2011:6). The Matthean community was in conflict with Formative Judaism, and the rabbi's education of the law was a heavy burden for those who believed in Jesus Christ and wanted to become members of the new faith community (Thiessin 2012:543-556; Cho 2017:79-201). The cause of the conflict between the Matthean community and Formative Judaism stemmed from differences in the interpretation of the law. There are many more various confrontations and conflicts found in the Gospel of Matthew. There are cases where people were struggling to forgive the sins of others (Mt 18) and cases of paraenesis to those who were not practising love.

On the other hand, there are many ideas of pacifism that focus on resolving confrontation and conflicts in the Gospel of Matthew. Jesus teaches his disciples to encourage and embrace the socially weak. It has made peace beyond conflict by embracing all classes of society. Also, Jesus taught that forgiveness is the way to resolve conflict

1 .In this article, pacifism is defined as a term that collectively refers to the emotional meaning in terms such as peace, compassion, forgiveness, love, prohibition meaning in terms such as peace, compassion, forgiveness, love, prohibition of retaliation and loving the eneachings of Jesus shown in the Gospel of Matthew. However, the pacifism in the Gospe of Matthew does not represent forgiveness, compassion or love for everyone such as the Pharisees. between brothers (Mt 18). Forgiveness was also the solution to the conflicts and crimes within the Matthean community. The teachings of forgiveness, which were the solution to the conflicts of the members of the Matthean community, can be applied to the situation of the people of North and South Korea who are in fact one nation. Also, Jesus in the Gospel of Matthew teaches to love. Jesus' disciples were taught to love the ones that prosecuted them (Mt 5:43-44). By looking at how Jesus' practice of love resolved conflict and confrontation, I would like to provide a basis to consider more pointedly how the two countries that are enemies can look towards future unification together. This article intends to explore how the pacifist ideas of embracement, forgiveness and love in the Gospel of Matthew can contribute to the emotional preparation of the unification of the Korean Peninsula.

\section{The conflicts between North Korea and South Korea and the Matthean community and Formative Judaism: A comparison}

The following sections will deal with the conflict between the two Koreas, divided after the Korean War, over the last 70 years and the conflict between the Matthean community and Formative Judaism. By comparing the situations of the two conflicts, I intend to find similarities between the two conflicts.

\section{The confrontational state after the division of North and South Korea}

North and South Korea have remained enemies after the Korean War. The two countries are actually one nation but inflicted pain on each other through war and is currently in a state of truce. To maintain their own ways, both Koreas imposed different political systems on their people. In North and South Korea, the after images of the Korean War have been internalised as political ideologies in all areas such as politics, economy, society, culture and the military. As the division became solidified the two Koreas conducted ideological education to maintain their systems, and the people of both countries were influenced by the country's political ideology (Lee 2011:166). The two Koreas, which were ideologically based on different ideas, continued to face confrontation and conflict, and the emotional disparity between the two Koreas grew even deeper.

The tragic history and the painful experiences of the past are personified in the two different people leading to the following emotional confrontation. Firstly, the peoples of North and South Korea are closed to and unaccepting of the other's political system. The Cold War system centred on the United States and Russia incorporated South and North Korea into its different ideological systems, and the Korean War further exacerbated the mutually exclusive relationship between the two Koreas (Park 1995:177). Eventually, South Korea chose to build a 'democratically free' nation and North Korea chose a 'communist' system. North Korea places the legitimacy of its establishment in the anti-Japanese armed struggle of Kim Il-sung, who resisted Japanese imperialism. 
On the other hand, the Republic of Korea inherited the legitimacy of the Provisional Government of Shanghai, which was established in 1919, and followed an anti-communist right-wing democracy (Chung 2007:6-7). The beginning of this exclusivity is because of the pain of division that has completely changed the national identities of the two Koreas (Park 2000:78-79).

The reason why the two Koreas are mutually exclusive is that they have different political and economic concepts. South Korea, which has chosen liberal democracy as its political ideology, recognises freedom, equality and private property systems. Freedom and equality are the most basic elements of human rights and are important terms symbolising the South Korean society and system. The Republic of Korea, which developed into a free market economy, advanced the idea that all humans were equal before the law. However, the market economy system by itself does not mean legal equality, and income is differentiated according to an individual's ability. On the other hand, North Korea insisted on communising all parts of the country and pursued a social system that calls for breaking down social classes. It denies the private property system and argues that all people are equal. Such different political and economic systems led to confrontation where both Koreas became more and more exclusive of each other as both strengthened different ideological systems.

Secondly, since the Korean War, North Korea has carried out continuous armed provocations with the aim of denying the existence of the Republic of Korea and destroying and overthrowing South Korean society. North Korea employed armed communist guerrillas and terrorist teams that brought confusion to South Korean society. North Korea sent secret agents to assassinate the South Korean president who visited Myanmar on 09 October 1983. This shocked the world as a large number of aides who accompanied the president on his presidential trip lost their lives. There was also an incident in which a South Korean civil aircraft was hijacked. Explosives were installed on a KAL 858 departing from Baghdad, Iraq, heading for Seoul's Gimpo Airport, killing 115 people on board, including crew, when the plane blew up over Myanmar's Andaman waters. Kim Hyun-hee, the North Korean secret agent who set up the explosives, was arrested and taken to Seoul to be sentenced to death, but she converted and now lives in South Korea. Even now, North Korea is waging numerous local wars with the intention of neutralising the Northern Limit Line on the west coast. Also, North Korea is heightening tensions in its attempt to turn Northeast Asia, as well as South Korea, into a powder keg with repeated nuclear tests. North Korea's armed provocation is still ongoing, and such an armed provocation does nothing to ease military confrontation and tension between the two Koreas.

Thirdly, the heterogeneity created by the two different educational systems of the two Koreas is affecting the sentiments of the peoples of both countries. The reason why the two Koreas, which are of the same ethnic group, lost their cultural homogeneity and increased their sense of alienation is because of different educational processes and contents. The educational goal of the Republic of Korea is to foster 'open, multifaceted human beings who can lead their own lives' to create 'Hong-Ik Human Beings' (Gyoyookbu 1997:87). ${ }^{2}$ Therefore, the Republic of Korea conducts education from elementary school upwards in view of cultivating rounded, creative and democratically minded citizens. The Republic of Korea, which aims for democratic education ideology, is to cultivate human resources who can contribute to society and humanity by prioritising individual self-realisation (Kim 2006:154).

On the other hand, education in North Korea is completely different from education in South Korea. North Korea's education is aimed to deify Kim Il-sung and Kim Jung-Il and make the people follow them. North Korea, which has communism as the foundation of its nation, is fostering 'communist new human beings' who value equality, collectivism, organisation and revolution (Bukhan-Yeonguso 2000:222-223). Therefore, North Korea's education is not interested in individual creativity and self-development, and it aims to foster uniform and passive human beings needed to maintain the regime. In other words, the priority is to educate the people to collectively become a 'uniform human being' that fits the communist community (Kim 2006:154). North Koreans, who have been educated in totalitarianism whereby only standardised orders are respected and obeyed, are bound to be rigid in thinking (Choi \& Lee 2000: 239-251). Such conflicting education has disparaged the culture and emotions of the people and served as a stumbling block to the unification of the Korean Peninsula. Therefore, for the unification of the two Koreas, it is imperative to unite disparate cultures and sentiments.

Since 2000, when the inter-Korean summit was held, both countries have consistently tried to ease the prevailing sense of hostility through various exchanges and cooperation. As a result, hostility towards North Korea within South Korean society was reduced. The South Korean government tried to embrace North Korea through the creation of tours to Diamond Mountains ${ }^{3}$ and the creation of an industrial complex in Kaesong city. But most of the reconciliation requests South Korea has made to the North Korean authorities have failed. The tour project to the Diamond Mountains was also shut down because of the North's unilateral move. The Kaesong Industrial Complex, invested by the South Korean government, was closed because of the North's excessive greed of economic needs and inhumane expansion and suppression of employees dispatched from South Korea. ${ }^{4}$ As a result, the Korean Peninsula remains in conflict with each other until today, still unable to break away from hostile confrontation. As a result, the aim to resolve the cultural and emotional disparities created by the two different educational systems has failed.

\footnotetext{
2.Hong-lk Human Beings is the educational concept of South Korea, which aims to benefit the human world widely.

3.The Diamond Mountain is located in North Korea which was open for South Korean tourists for a while.

4.The Kaesong Industrial Complex was shut down on 11 February 2016.
} 


\section{The situation of conflict between the Matthean community and Formative Judaism}

The Gospel of Matthew shows the background of the life and faith of the members of the Matthean community. During the past century, scholars have focussed their study of what type of faith community the Matthean community was and achieved considerable results. Efforts were also made to study what the relationship between the Matthean community and Formative Judaism was like, and in so doing to reimagine the situation of the members of the Matthean community who were trying to build a Christian identity (Saldarini 1994; Sim 1998; Stanton 1992:280). Secretly speaking, the Matthean community was facing a transitional situation where separation from Judaism was in progress. The Matthean community, which was separating from Judaism, was still struggling to break away from the teaching of obeying the law, which was the core teaching of Judaism. The Matthean community, which was transitioning to Christianity displayed some peculiar characteristics. The members claimed that they constituted a community different from Judaism, as expressed by the word 'righteous' in the Gospel of Matthew (Mt 5:6, 10, 20, 6:1) (Overman 1990:16-19). The 'righteous' used in the Gospel of Matthew means that although the Matthean community started as a parent body of Judaism, it gradually developed into a new religious community separated from Judaism. The Matthean community, which was in a process of separating from Judaism, naturally developed its identity whilst standing in conflict with Formative Judaism (Repschinski 2000).

The conflict between the Matthean community and Formative Judaism played out as follows. Firstly, the conflict between the newborn Matthean community and Formative Judaism began from comparing the teachings of Jesus and the Pharisees with each other. The Gospel of Matthew depicts a disciple as someone who follows the teachings of Jesus. The disciples of Jesus did not focus on observing the law, which is the teaching of Formative Judaism, but focussed on practising the words of Jesus (Shin 2019:3). Instead of the law, the Matthean community placed the teachings of Jesus at the centre of the formation of its religious identity. The Pharisees, on the other hand, taught the people of Israel to teach and obey the law. There was a clear gap between the disciples who wanted to keep and obey Jesus' words and the Pharisees who wanted to obey the law. The Matthean community tried to practise Jesus' teachings whilst giving it an authority equal to the Law of Moses (Mt 24:35) (Shin 2019:4).

However, in the Gospel of Matthew, a more intense conflict between Jesus and the Pharisees over the authority of teaching appears. The Pharisees (rabbis) at the centre of the Formative Judaism listened to the authoritative interpretation and teachings of Jesus and feared for the loss of their vested rights (Mt 15:12) (Shin 2012:94-95). The teachings of Jesus influenced many groups and the groups marvelled at Jesus (Mt 7:28; 13:54; 22:30-33). Moreover, Matthew's repeated emphasis on how wonderful and amazing the teachings of
Jesus were was a testament to the fact that the people of Israel were becoming assimilated to the teachings of Jesus, and in fact, the crowd acknowledged the authority of Jesus' teachings (Luz 2005:73). The fact that the people of Israel had given authority to the teachings of Jesus was a defeat and shame that was unacceptable for the Pharisees.

Jesus said to the Pharisees, who boasted the authority of teaching, 'Every plant that my heavenly Father has not planted will be pulled up by the roots' (Mt 15:13). This phrase implies Jesus' assessment of the Pharisees' teachings, meaning that the Pharisees' teachings did not stem from the authority God. What God wanted to plant in this world was for the people of Israel to be saved. However, although the Pharisees tried to teach the people of Israel by correctly interpreting the word of God, they ended up planting their vested rights and authority on the people instead of planting what God wanted them to plant (Luz 2001:333). Jesus indirectly pointed out the Pharisees' wrong salvation of the people of Israel. Moreover, it can be seen how Matthew despised the Pharisees' teachings when he used the expression 'pulled by the roots' (Shin 2012:96). 'Pulled by the roots' (Mt 15:13) is a term symbolising apocalyptic judgement, which means that what was planted has lost all value. The disciples of Jesus tried to have no business with the Pharisees who were like blind men who led the people of Israel to the wrong path (Mt 23:16, 24) (Luz 2001:333). The ministry of Jesus was to heal the blind and the Pharisees were spiritually blind, meaning that the Pharisees did not deserve the authority to teach the people of Israel but rather had to be taught by Jesus. The Pharisees were said to be spiritually blind because even though they taught the people of Israel, they themselves could not accurately deliver the word of God because their interpretation of the law differed from that of Jesus (Luz 2001:333). The Matthean community, who followed Jesus' teachings, and the Pharisees, who wanted to abide by the law, were at odds with each other over who had the authority to interpret and teach the law.

Secondly, the conflict between the Matthean community and Formative Judaism was over whether Jesus had the authority to forgive sins, which is well illustrated in the case of the cure of the paralytic (Mt 9:6). In the Gospel of Matthew, 'forgiveness of $\sin ^{\prime}$ is a very important subject (see Baker 1994:224-235; Illian 2010:444-450; Mbabazi 2013). However, the reason why the Matthean community was at odds with Formative Judaism was because of their different understanding of the forgiveness of sin. According to Jesus, Formative Judaism, formed after the destruction of the temple in Jerusalem, needed a new concept of 'forgiveness of $\sin ^{\prime}$. This is because there was no longer a way to receive 'forgiveness of $\sin ^{\prime}$ from the temple service (Mt 9:12-13). At the time of Jesus, the Jews thought of the 'forgiveness of $\sin ^{\prime}$ in the following terms. Early Jews had no perception that they had to receive 'forgiveness of sin' from God and did not even recognise themselves to be sinners. This is because they were God's promised people (Neusner 1975:25). After the destruction of the temple in Jerusalem, the Jews regarded 
themselves as a righteous people who did not need to be forgiven for their sins because they obeyed the law.

However, the Matthean community believed that Jesus, the 'son of man', had the authority to forgive sin (Mt 9:5). The authority (exousia) Matthew spoke of quotes the content from Daniel 7:13-14, which speaks of the 'son of man' who approached the Ancient of Days and had the power to forgive sin (Davies \& Allison 2012:33). This led Jesus to observe that it was easier to say 'your sins are forgiven' than to say 'your diseases are healed'. Matthew 28:18 clearly states that Jesus has all authority, which would include his authority to forgive sins. It means that Jesus, who ascended, had all the power in heaven and earth, so he of course also had the authority of forgiving sin on earth (Luz 2001:28-29; Shin 2012:96).

The Pharisees, who followed the perspective of the scribes and denied the authority of Jesus, saw it as blasphemy that Jesus declared 'forgiveness' according to the scribe's point of view. They considered it to be an act of blasphemy for Jesus to say he forgives sin. The rabbis believed that only God could forgive the sins of humans (Charlesworth 1992:834). However, Matthew repeatedly mentions that it is possible to forgive sin on this earth. The Lord's Prayer reads, 'For if you forgive other people when they sin against you, your heavenly Father will also forgive you' (Mt 6:14). It was shown that there was a connection between God's forgiveness of human sins and man's forgiveness of human sins. Moreover, the expression 'If you forgive sin on this earth, your heavenly Father will forgive you sins' shows how God's forgiveness of sin seems to be deeply related to human life (Mt 18:15-35). This means that the members of the Matthean community, who witnessed Jesus' forgiveness of sin on this earth, acknowledged Jesus' forgiveness of sins. This is because the Matthean community recognised Jesus' crucifixion and sacrifice as forgiveness of sins (Mt 26:28). The Matthean community believed that Jesus had the authority to forgive $\sin$. Moreover, Historical Jesus was a religious heritage of the Matthew community (Sim 2011:2; see Catchpole 2006), and so the Matthean naturally believed forgiveness of sin was possible. The Jews, on the other hand, regarded Jesus' actions as blasphemy because they could not accept Jesus' authority of forgiveness of $\sin$.

Thirdly, Jesus was at odds with Formative Judaism because he did not always observe all the purity laws of Judaism. The Pharisees, who emphasised the Jewish law of purification, warned against dining out with lower-class people defined as 'unclean' (Ottenheijm 2001:5). Jesus, however, ignored the rules of the law and shared table companionship with the lower classes of society such as tax collectors and sinners (Mt 9:9-13). This incident illustrates how Jesus showed the Pharisees that it is far better to serve God with the heart than with outward actions. From the Pharisees' point of view, Jesus' table-to-table intercourse with the lower classes of society signified disobedience to God's order to maintain holiness (Hagner 1993:238-239). Moreover, judging from
Jesus' eating habits, he was an important figure in table companionship hosted by sinners and tax collectors. The phrase 'when Jesus sits down and eats' (auvtou/avnakeime, nou) points to the way in which Jesus was 'sitting down leaning' (Shin 2012:98) when he was eating. Therefore, the phrase, 'sitting down leaning' (auvtou/avnakeime, nou), which is a form of genitive absolute indicates that Jesus was a guest of honour (Hagner 1993:238).

The fact that Jesus ignored the Jewish rule and had table companionship with lower-class people is proof that the Matthean community had direct confrontation with Formative Judaism. Jesus' actions, through which he showed acceptance of the Scribes (Mt 13:52) and the lower classes of society (tax collectors, sinners) as the people of the Kingdom of God, led to confrontation that clearly showed conflicting positions (Shin 2012:99).

Just as the two Koreas look at each other from an exclusive point of view, the Matthean community and Formative Judaism were also at odds with each other from an exclusive point of view. The exclusive relationship is why the two Koreas have lost the identity of the same people. Just as the two Koreas have antagonised each other through the use of military force, the Matthean community and Formative Judaism had been at odds, blaming each other. And just as the two Koreas have armed their people with different educational content, the Matthean community and Formative Judaism had confronted each other with different educational ideologies concerning Jesus' teaching and compliance with the law. Thus, the confrontation and conflict between the Matthean community and the Jewish community during the formation period are quite similar to the present-day confrontation between the two Koreas. However, the primary purpose of Jesus' pacifism in the Gospel of Matthew was not to resolve the confrontation between the Matthean community and Formative Judaism. It was more important to the Matthean community to apply Jesus' pacifism to their lives despite internal and external conflicts.

\section{Emotional bond in the Gospel of Matthew as incentive for the peaceful reunification of the Korean peninsula}

Amongst the teachings of Jesus' pacifism in the Gospel of Matthew, there are about three guiding principles that should be directed towards the unification of the Korean Peninsula. They are inclusion (Mt 8:3; 15:20; 23:25-26), forgiveness (Mt 5:7; 6:14; 9:13; 12:7; 18:21-22) and love (Mt 5:44; 22:34-40; 19:16-22). Because the confrontation between the Matthean community and Formative Judaism does not totally coincide with the confrontation between the two Koreas, only some parts will be compared. The Gospel of Matthew has factors that can give suggestions and contributions on raising emotional homogeneity for the unification of the Korean Peninsula in this article. 


\section{Embracement (engagement policy)}

In the past seven decades after the Korean War, the two Koreas have mostly run the path of confrontation and conflict (Chang 2016:1-17). There were, of course, temporary gestures of reconciliation, but these were largely political slogans and echoes, and they did not develop in the direction of pursuing genuine reconciliation and peace. In fact, the two Koreas pushed for various meetings by coordinating each other's stances. Fundamentally, however, they had little intention of embracing the other. Selfish negotiations and attempts to subdue the other party led to failure of creating an atmosphere of genuine reconciliation. In other words, the South Korean government and its private organisations have sought to bolster continued aid and cooperation with the North, but the North Korean government has not really accepted it (Kim 2013:200-2004). The two Koreas have been so different emotionally over the past 70 years and clearly emotionally distant to embrace each other (Song 2012:47-48). Also, it would not be easy for the two Koreas to exercise emotional engagement as their attitudes towards each other have been based on conflict and confrontation (cf. Cho 2014:453-479). In the end, the failure of South Korea's engagement policy towards North Korea is fundamentally because of North Korea's invariance, its continued nuclear armament and its adherence to socialism (Shin 2014:184).

The Gospel of Matthew describes Jesus' ministry as fairly inclusive (Shin \& Van Aarde 2005:1353-1372). The firstcentury Mediterranean society was all about social class, and it sustained a clear distinction between social classes (Duling 2002:520-575). In particular, the Jewish community formed a religious system that distinguished the extent of the human person's holiness based on the temple (Elliot 991:103-104). As a result it was very difficult for a first-century society to move from one class to another, because of the clear distinction between classes. Members of the upper class of Jewish society, especially religious leaders (centered in Formative Judaism), endeavoured not to engage or make physical contact with members of the lowest class (Shin 2004:226-227). However, Jesus worked as a teacher and one of his works was embracing the lower classes of society, who were subject to disregard and disdain. In the Gospel of Matthew, the lower classes of society were isolated and were mainly the sick, the unclean, the possessed and the gentiles.

Jesus touched the leper's body and healed him (Mt 8:3). The Jewish Purity law was based on the Law of Moses, which stipulated that no contact should be made with an unclean person (Lv 13-14). Judaism had established itself on the customs of the first-century Jewish community to the extent that it has had a certain impact on the Halakhah and Mishnah of rabbi Judaism (Hay 2007:750). In ancient society, leprosy was defined as unclean and was perceived as a truly painful disease. That is why making contact or having a relationship with a leper was considered to be an act of uncleanness (Talbert 2010:112). According to the Old Testament, lepers were treated in a peculiar way. If a man had leprosy, people believed that he was judged by God because he committed a sin that could never be forgiven (Nm 12:10-15). And even when alive, a person with leprosy was treated as a dead man (Job 18:13). For this reason, lepers were defined as unclean according to the rules of the law and were perceived negatively in society. The fatal difficulty for lepers was the fact that they could not belong to any community. This is because people were warned not only to avoid leprosy, but also not to get close to lepers ( $\mathrm{Lv}$ 13:45). The Pharisees of Jesus' time, too, followed the purity law of the Old Testament. They did not accept lepers as members of society and hence considered them as people who should be avoided (Chilton 2000:877). Lepers were miserable beings who had to live in isolation away from their communities (Davies \& Allison 2012:11).

The religious leaders in the time of Jesus also had no emotional room to embrace lepers. This is because religious leaders believed that strictly following the rules of purity prescribed by the law was the way to maintain their religious purity (Mt 15:20; 23:25-26). The lepers who were the target of criticism in society were able to return as members of their original communities only if they were confirmed to have been cured of the disease ( $\mathrm{Nm} \mathrm{12;} 2 \mathrm{Ki} \mathrm{5:1-15).} \mathrm{Thus,} \mathrm{at} \mathrm{the}$ time of Jesus, rabbis did not feel the emotional need to embrace an unclean leper. Rather, they regarded lepers, who were socially disadvantaged, as filthy and unclean.

What was absolutely necessary for lepers isolated from existing communities was the attention of family members or acquaintances. From this point of view, the fact that Jesus reached out and touched a leper was a fairly unconventional embracement policy that no one in society could tolerate at the time. Formative Judaism, which sought to abide by the rules of the law, taught people not to make contact with those who had leprosy, but Jesus showed an inclusive attitude including lepers as the people of God. Matthew described that Jesus' inclusiveness shown through healing ministry was the Messiah inclusion the people of Israel expected. Jesus showed inclusion by not only healing lepers, but also healing and taking away the weaknesses and diseases of all people including the possessed (Mt 8:16-17) (Talbert 2010:111).

The fact that Jesus' healing ministry embraced leprosy primarily means that lepers had been cleansed. Leviticus 13-14 shows what people with skin diseases should do. Those who had skin problems first had to isolate themselves and inform others that they had become unclean because of skin diseases. They had to 'wear torn clothes, let their hair be unkempt, cover the lower part of their face and cry out, “Unclean! Unclean!"' (Lv 13:45). The leper shouting 'unclean' was to warn others that they too might be unclean because of him or her and at the same time contains a wish to purify himself or herself from leprosy (Viljoen 2014:5)

The cries of the lepers included agony because of the isolation and disconnection from society. Therefore, Jesus healing and restoring an unclean person with leprosy was beyond merely healing the leper's physical illness. The healing of skin diseases in ancient Mediterranean society meant 
restoration of one's life and honour. Those who had been cured of skin disease or leprosy could return to their former societies. Jesus' healing of leprosy not only restored the person's social status, but also gave new meaning to the person's life. Therefore, Jesus' act of healing leprosy showed an inclusive attitude that restored the social status of the person who was considered unclean and as a result socially isolated from Formative Judaism. The conventional wisdom and Jewish rules of that time considered leprosy as unclean and filthy and isolated lepers. In contrast Jesus' healing ministry held the inclusive value that suggested that Lepers be healed and still be considered as members of the Kingdom of God. Against this backdrop it is postulated that the ministry of inclusiveness shown by Jesus in the Gospel of Matthew could serve as emotional background for the unification of the Korean Peninsula, which has been suffering from division for the past 70 years.

\section{Forgiveness}

One of the essential factors in eliminating emotional barriers is forgiveness. The reason why inter-Korean relations need forgiveness is because the North has caused considerable human and material damage to the South because of its armed provocations. As a result, inter-Korean relations have become filled with animosity, and emotional harmony is needed to reconcile them. As already noted, the South is constantly trying to reconcile with the North, but the North's continued sabre-rattling has made the South Korean people recognise the North as an unreliable terrorist group. Amongst the North's armed provocations, one big incident occurred that angered the South Korean people. Park Wang-Ja received a tourist visa in accordance with a due process and visited the Diamond Mountains, a North Korean area. She was shot to death by a North Korean guard at Jang-Jeon Port whilst strolling along a coastal road early on 11 July 2008. This is a violation of a joint inter-Korean agreement on guaranteeing the safety of tourists. It was a harsh act of hostility to shoot a civilian tourist, not an accident caused by a physical military confrontation between the two Koreas. After the incident, relations between the two Koreas entered a prolonged cooling-off period, and relations between the two countries were burning with intense hostility. South Koreans branded North Korea as an enemy that is hard to forgive. ${ }^{5}$

A prerequisite for the two Koreas to overcome the pain of civilian shootings and achieve unification is an emotional preparation for reconciliation. Conditions of reconciliation that can resolve hostile confrontations towards each other begin with forgiveness. Let us shed light on the emotional possibility that the two Koreas can overcome confrontation and conflict and forgive each other by upholding the case of brotherly forgiveness within the Matthean community (Mt 18:21-22). Traditionally, if a person commits a crime, Jews thought it would be enough to forgive the person up to three times (b. Yoma 86b-87a). The tradition of Formative Judaism during the first century also says if a person commits a crime, it is wise to forgive those who commit crimes up to three times (Davies \& Allison 2012:793). But Peter asked Jesus if he should forgive the sins of the same sinner as stated in the Jewish tradition up to seven times, not three times (Mt 18:21). Peter's suggestion of forgiving seven times has to do with retaliation. This is because the phrase 'forgive seven times' implies to stop retaliation against those who hurt him, which ultimately means to show complete forgiveness.

During Old Testament times, the people of Israel offered atonement services for their sins. The greatest purpose of atonement service was to be forgiven by God in the presence of God. Because the people of Israel were afraid of God's punishment, they practised a service of atonement in anticipation of the God of love, not the God of retribution. The form of atonement service was as follows. The priest would burn incense first to reveal God's glory, whilst keeping God from seeing sin, and not allowing the sinner to suffer from the wrath of God. Then the priest would 'take some of the bull's blood and with his finger sprinkle it on the front of the atonement cover'. Thereafter he would sprinkle some of the blood 'with his finger seven times before the atonement cover' (Lv 16:13-14). This symbolises the complete forgiveness of sins. Therefore, Peter asked whether to forgive sinful brothers up to seven times based on the tradition of the Old Testament's atonement service.

Let us delve deeper why Peter emphasised forgiving sin up to seven times. If Matthew 18:21-22 is talking about the need for brother forgiveness, this should be seen as forgiveness of sins caused by conflicts within the community, even without the grammatical interpretation of the text of Chapter 18. This speculation is possible because the term ska, ndalon used in 18:6-9 means to cause other brothers to fall. The forgiveness shown in Matthew 18:21-22 does not pertain to religious crime between human beings and the divine, but it is a matter of human relations within the community (Park 2006:224-226). In the event of a conflict between members of the Matthean community, if sinners refuse to admit their sin, it is said that they should be treated like gentiles and tax collectors (cf. Mt 5:43-48). To treat sinners as gentiles implies thinking of them as enemies. When interpreting Leviticus 19:17-18 from the point of view of Formative Judaism, the term 'enemy' is in contrast with the term 'neighbour', which, if possibly interpreted correctly, 'enemy' in Matthew 5:44 means a gentile (Luz 2007:287). The reason why the people of Israel considered gentiles as enemies was because they had been persecuted and invaded by gentiles. However, the Matthean community could not resist Jesus' teachings about loving the enemy (see Thiessin 1992:135-136). This is because Jesus, as depicted by Matthew, sought forgiveness by teaching to stop retaliation and loving the enemy. Because the Matthean community was a community of God existing on earth, it had to practise forgiveness which was a law of the community of God (Mt 5:7; 6:14; 9:13; 12:7). 
Because this teaching of forgiveness was important and subscribed by the Matthean community, Peter asked whether he should forgive up to seven times from a broad perspective of even loving enemies. In response to Peter's question, Jesus had ordered to forgive even 77 times (Mt 18:21-22). It can be interpreted that the intention of the author of Matthew of this passage was not to limit the forgiveness of sins. The rationale for Matthew's assertion of infinite forgiveness was that the number seven was a Jewish traditional number representing completeness (Luz 2001:465). It can be asked why Matthew tried to teach the community members to apply into their lives the teaching of completely forgiving other members despite conflicts and quarrels. Matthew suggested mutual forgiveness amongst community members. 'For if you forgive other people when they sin against you, your heavenly Father will also forgive you. But if you do not forgive others their sins, your Father will not forgive your sins' (Mt 6:14-15). The Matthean community taught the members to forgive each other even if they were enemies. Therefore, Jesus' teaching of forgiveness is an example that shows that forgiveness is the emotional aspect needed to heal the enemy relationship of the two Koreas caused by conflict.

\section{Love}

South and North Korea have blamed each other for the past seven decades since the division of the Peninsula. North Korea's propaganda phrases against the South have always been flooded with postings of criticism. More than 2.41 million anti-South Korean flyers were sent shortly after the division of the Peninsula (Choi 2018). North Korea's flyers sent to the South included stringent content about 'not only criticizing the South Korean president but also mercilessly punishing the South' (Choi 2018). North Korean authorities expressed their anger towards the South Korean government with merciless criticism. Some argue that the propaganda that North Korea sent to South Korea in rubber balloons is crude hand writing and drawing that is nothing but hateful and childish reaction to South Koreans living in a high-tech era (Choi 2018). On the other hand, propaganda from South Korea to North Korea seems to have had a significant effect. The spread of propaganda materials by civic groups centred on North Korean defectors contained data that could compare the economies of the two Koreas, which had a fatal impact on North Koreans. The North's incitement and criticism that South Korea is overflowing with beggars has been revealed to be false by flyers sent by North Korean defectors. The South Korean president ordered private organisations to seek ways to refrain from sending anti-North Korea flyers to the North as they could lead to accidental military clashes.

A solution that will help the two Koreas stop criticising each other at this point in time is to share emotions of love. The importance of love has always been emphasised in any era in human history. From this vantage point let us consider how the love taught by Matthew's Jesus may inspire the people of the two Koreas to share the dictum of love with each other. During the time of Jesus, the Pharisees believed that there was a great sense of respect for the observance of the law, and thought that the Ten Commandments must be kept (b. Qidd. 40; p. Ned. 3:9). During this time, Jews believed obedience to their parents was the biggest commandment, but some stated that love was the biggest commandment (Bonsirven 1964:29; Montefiore \& Loewe 1974:111). The rationale for the claim that the biggest commandment of the law is 'neighbourly love' was found in Leviticus 19:18 (Sifra Qed. pq. 4.200.3.7; Gen. Rab. 24:7) (Kenner 2009:531). At the time of Jesus, the Pharisees had a clear standard of value for interpreting the law and acknowledged that the greatest commandment of the law was love (Kenner 2009:531).

However, Jesus, as depicted by Matthew set a standard that surpassed the notion of love claimed by the Pharisees (Mt 22:34-40). As already noted, the Jewish leaders of Formative Judaism complied with the code of law to practise love on a perfunctory level. The Jewish leaders liked to boast how they were obeying the law and did not truly follow the commandments of love. The second of the commandments of love that Jesus taught the Matthean community quotes Leviticus 19:18, which speaks of loving your neighbour as yourself. Both Jesus and the Pharisees raised the need for neighbourly love through the same Leviticus text, although the line of interpretation is completely different. The Pharisees pursued an instructive approach to neighbourly love in accordance with the consciousness of observing the law. Jesus instead presented neighbourly love from a practical perspective. His order to love 'your neighbour' implies a definition of neighbour. As previously stated, Jews generally considered 'enemies' as 'gentiles', and the term 'neighbour' was used to define homogeneous people.

Leviticus 19:17-18, which Jesus quotes in Matthew 5:44, clearly shows the definition of neighbour. It reads, 'Do not hate a fellow Israelite in your heart. Rebuke your neighbour frankly so you will not share in their guilt. Do not seek revenge or bear a grudge against anyone among your people, but love your neighbour as yourself. I am the Lord'. The neighbour in Leviticus 19:17-18 refers to people of the same race. When considering the meaning of 'neighbourly love' within the Matthean community, it emphasises the love between members of a mixed community, which is one body consisting of Jews and gentiles (Luz 2007:587). The root of Jesus' teaching deals with love amongst the same people, and the phrase 'love your enemy' means to change the hatred towards the enemy into love (Mt 5:44) (see Davies \& Allison 2006:552). The teaching of not avenging or hating the same race means to not to think of revenge. This is because when the mind for revenge becomes dominant, it becomes despicable and makes it impossible to live a spiritual life as the people of God. And because revenge belongs to God, we must leave it to God (Dt 32:35). Moreover, 'love your neighbour as yourself' means to love and show grace to others as yourself (Hartley 1992:317318). As a result, if the purpose of Jesus' teaching to love your enemy can be interpreted as loving your own people, it can be an emotional ideology for the people of the two 
Koreas who are repeating the pain of confrontation and conflict. Churches and missionary groups in South Korea are promoting emotional homogeneity through faith by establishing a heart hospital in Pyongyang and unofficially delivering the Bible to North Korea to show the love of Jesus Christ to North Korea (cf. Do 2018). This is because the people of the two Koreas are a single nation that has shared the same language and culture over the past 5000 years (Kim 2018:68). ${ }^{6}$

\section{Conclusion}

This article explored the possibility of the two Koreas to seek a path of peace beyond confrontation and conflict from the perspective of the pacifism of Matthew. Of course, it is unclear whether the path of harmony and peace proposed by the Gospel of Matthew can improve the current situation of the Korean Peninsula. However, if the two Koreas could reach the point where they can find an emotional homogeneity that can be shared by the people of the two Koreas, which can be the ideological basis for peaceful unification, they can develop this idea and lay the foundation for future unification.

The level of pacifism displayed in the Gospel of Matthew also originated from a situation of conflict and confrontation between the Matthean community and Rabbinic Judaism. Jesus, as depicted by Matthew, proposed inclusiveness, forgiveness and love as a way to resolve conflicts and confrontations. Jesus' teaching of inclusiveness confronted the rules of the Jewish law of Formative Judaism, which called for the social isolation of people with skin and other diseases. Jesus' teaching of inclusiveness also raised the need to proclaim the kingdom of God to everyone beyond social class and status. Forgiveness is the answer to confrontation and conflict within human relationships that are hard to forgive. Religious leaders who were the centre of Formative Judaism sought formal forgiveness, but Jesus taught true forgiveness that the Matthean community sought to put into practice. The mind of forgiveness constituted the driving force behind the drive to create a desire for peace and pursue reconciliation. Therefore, I think Jesus' teaching of forgiveness can contribute to the peaceful reunification of the two Koreas in the future. Also, Jesus, depicted by Matthew, emphasised the love for God and love for neighbours. Neighbourly love means love for one's own people. In this respect, the Gospel of Matthew gives us a clue that emotional bonding is needed for the two Koreas, which is one ethnic group, to achieve peaceful unification. By applying the pacifism teachings of Jesus, we should perceive the people of the same race as people to love, not as enemies or as persecutors.

The Matthean community and Formative Judaism constantly walked the path of confrontation, and the confrontation could have been alleviated if both groups applied Jesus' teachings of pacifism. The Matthean community accepted Jesus' teachings through the disciples of Jesus and used pacifism as its emotional value criterion, whereas the Pharisee-centred Formative Judaism did not accept this pacifism. Seventy years after the division, the two Koreas are also recreating the conflict between two communities that are reminiscent of the division in the Gospel of Matthew. Today, for the two Koreas to have a brighter future, the teachings of Jesus set the prime example. Yet, even though this article calls for emotional homogeneity for peaceful unification of the Korean Peninsula by following the Gospel of Matthew, it is closer to being a clue for the solution rather than being a direct solution.

\section{Acknowledgements Competing interests}

The author has declared that no competing interest exists.

\section{Author's contributions}

I declare that I am the sole author of this research article.

\section{Ethical consideration}

This article followed all ethical standards for a research without direct contact with human or animal subjects.

\section{Funding information}

This research received no specific grant from any funding agency in the public, commercial or not-for-profit sectors.

\section{Data availability statement}

Data sharing is not applicable to this article as no new data were created or analysed in this study.

\section{Disclaimer}

The views and opinions expressed in this article are those of the author and do not necessarily reflect the official policy or position of any affiliated agency of the author.

\section{References}

Ahn, I.S., 2017, 'Teug-jib: Tong-il sinhag jeonglib-eul-wihan gaehyeog juuijeog gochal: Augustine (354-430) ui sasang-eul joongsim-eulo', Hankuk gyehyeog sinhag 53 , 198-222. https://doi.org/10.34271/krts.2017.53..198

Baik, C.H., 2016, 'Sinhaghaneun sil-cheon: Sam-wi-ilchejeog pyeonghwa tong-i sinhag-ui jeog-yong: Bughan i-tal jumindeulkwa hanguk sahoewaui sang-ho ihaewa pil-yo-eul joongsim-eulo', Hankuk gyehyeog sinhag 49, 132-162.

Baker, R.A., 1994, 'The forgiveness sin', Review \& Expositor 41(3), 224-235. https:// doi.org/10.1177/003463734404100302

Bonsirven, J., 1964, Palestinian Judaism in the time of Jesus Christ, Holt, Rinehart \& Winston, New York, NY.

Bughan-Yeongu-so, 2000, 'Bughan', 2wolho, Bughan-Yeongu-so, Seoul.

Catchpole, D., 2006, Jesus people: The Historical Jesus and the beginnings of Community, Baker Academic, Grand Rapids, MI.

Chilton, B.D., 2000, 'Purity', in C.A. Evans \& S. E. Porter (eds.), Dictionary of New Testament background, pp. 874-882, Inter Varsity Press, Downers Grove, IL/ Leicester. 
Chang, K.R., 2016, 'The first inter-Korea summit meeting 2000: An explanation on the long-term conflict theology', Inmungwa Sahoe 21(7), 1-17. https://doi. org/10.22143/HSS21.7.6.1

Charlesworth, J.H., 1992, 'Forgiveness', in D.N. Freedman (ed.), The Anchor Bible Dictionary, V2 D-G, pp. 833-835, Doubleday, New York.

Cho, E.J., 2014, 'Hankug jeonjaeng-gwa munhwa (in) ui baechi-jeogchi- 90il-ui seonjeonseondong sa-eobgwa munhwa gongjagdae hwaldong', BangyoeomunYeongu 38(0), 453-493.

Cho, J.H., 2017, 'The Sabbath law controversy between the Matthean community and Formative Judaism (Mt 11:28-12:14 and 24:20)', Canon \& Culture 11(2), 179-201. https://doi.org/10.31280/CC.2017.10.11.2.179

Choi, H.H. \& Lee, H.B., 2000, 'Bughan kyogwaseo bunseog-eul tong-han cheongsoyeon gachigwan yeongu: godeung junghaggyo gongsanjuui dodeog 3, 4 hagnyeon jungsim-eulo', Bughan-yeonguhaghoebo 4(2), 235-267.

Choi, U.S., 2018, Bughan-ui boggopung daenamgongjag-in jeondan jagjeon: Bughan, 2016 yeon 1 wolbuteo 2017 yeon 9 wolka-ji yag 241 man-yeo jang ppila ppulyeo,
viewed 21 January 2020 from http://monthly.chosun.com/client/news/viw.asp?c viewed 21 January 2020 from http://mc
tcd $=$ H\&nNewsNub=201801100026.

Chung, Y.C., 2007, 'The structure of antagonistic symbol between South and North Korea and its change', Bughan-yeonguhaghoebo 11(1), 1-23.

Davies, W.D. \& Allison, D.C., 2006, A critical and exegetical commentary on the Gospel of according to Matthew 1-7, ICC, T \& T Clark, London.

Davies, W.D. \& Allison, D.C., 2012, A critical and exegetical commentary on the Gospel of according to Matthew 8-18, ICC, T \& T Clark, London.

Do, J.K., 2018, Pyeong-Yang simjangbyeong-won gongsa jaegae hab-ui hab-ui haessda: Pyongyang Heart Hospital Construction, viewed 18 April 2020 from
http://news.khan.co.kr/kh_news/khan_art_view.html?art_id=201804251827001 http://news.khan.co.kr/kh news/khan_art_view.
\#csidx19f1e86e8c75ae18775e6959e1e16b2.

Duling, D., 2002, 'Matthew as marginal scribe in advanced agrarian society', HTS Theological Journal 58(2), 520-575. https://doi.org/10.4102/hts.v58i2.563

Gyoyugbu, 1997, Chodeunghagkyo kyoyuggwajeong haeseol(1), Gyoyugbu, Seoul.

Hagner, D.H., 1993, Matthew 1-13, Thomas Nelson, Dallas, TX. (WBC 33).

Hartley, J.E., 1992, Leviticus, Word Books, Dallas, TX. (WBC 4).

Hay, C., 2007, 'Purity and impurity, ritual', in F. Skoling \& M. Berenbaum (eds.), Encyclopaedia Judaica, 3nd edn., vol. 16, pp. 746-756, Thompson Gale, Detroit.

Hur, H.Y., 2010, Tong-il-eul wihan kidoggyosinhag mosaeg: Namnam mich nambug galdeung-gwa tonghabjeog tong-il sinhak, dong-yeon, Seoul.

Illian, B., 2010, 'Church disciple and forgiveness in Matthew 18:15-35', Currents in Theology and Mission 37(6), 444-450.

Jeon, U.T oe 9in, 2014, Tong-il-e daehan Kidoggyo-jeog seongchal: Jeung-owa baeje-ui nonlileul neom-eo poyong-gwa hwahab-ui madang-eulo, Saemulgyeol peulleoseu, Seoul.

Joo, D.H., 2015, Tongilro hyanghan kyoheaul gil, Kidokkyomunseosunkyohoe, Seoul.

Kenner, C.S., 2009, The Gospel of Matthew: A social-rhetorical commentary, William B. Eerdmans, Grand Rapids, MI.

Kim, G.S., 2013, 'Kimjeong-eun sidae bughan-ui daeoehyeoblyeog byeonhwawa daenam jeongchaeg: "seontaegjeog byeonghaeng" jeonlyag-eul jungsim-eulo', Hanguggwa kugje Jeongchi 29(1), 193-224.

Kim, M.O., 2018, 'Dangunsinhwa insig-e daehan yeogsajeog gochal', Yeogsawa Yunghá 12(3), 45-86.

Kim, Y.D., 2006, 'Nambughan ijilhwa geugboggwa tong-il gyoyug-e gwanhan gochal', Yunligyoyug-yeongu 11(4), 145-171.

Lee, B.S., 2011, 'Nature and ethics inherent in the trauma of division', Sidaewa Cheolhag 22(1), 153-183.

Lee, I.S., 2012, 'Baul-ui sanghwang-gwa sinhag-eul tonghan bughan seonkyo jeonyag', Kidoggyowa tong-il 6(0), 143-161.

Luz, U., 2001, Matthew 8-20, transl. J.E. Crouch, Fortress, Minneapolis, MN. (HCHCB). Luz, U., 2005, Matthew 21-28, transl. J.E. Crouch, Fortress, Minneapolis, MN. (HCHCB). Luz, U., 2007, Matthew 1-7, transl. J.E. Crouch, Fortress, Minneapolis, MN. (HCHCB). Mbabazi, I.K., 2013, The significance of interpersonal forgiveness in the Gospel of Matthew, Pickwick Publishing, Eugene, OR.
Montefiore, C.G. \& Loewe, H., 1974, A rabbinic anthology, Schocken, New York, NY. Neusner, J., 1975, First-century Judaism in crisis, Abingdon Press, Nashville, TN.

Neville, D.J., 2007, 'Toward a theology of peace: Contesting Matthew's violent of eschatology', Journal for the Studies of New Testament 30(2), 131-161. https:// doi.org/10.1177/0142064X07084773

Ottenheijm, E., 2001, 'The shared meal-a therapeutical device the function and meaning of Hos 6:6 in Matt 9:10-13', Novum Testamentum 53(1), 1-21. https:// doi.org/10.1163/156853610X493009

Overman, J.A., 1990, Matthew's Gospel and formative Judaism: The social world of the Matthean community, Fortress, Minneapolis, MN.

Park, J.S., 2006, 'Sündenvergebung im Matthäusevangelium', Evangelische Theologie 66(3), 210-227. https://doi.org/10.14315/evth-2006-0306

Park, J.S., 2012, 'Teugjib 1: tong-ilgwa sinhag: tong-ilsinhag-ui seongseo sinhagjeog jeobgeun-e daehan silon', Kidoggyo tong-il haghoe 6(0), 27-37.

Park, M.C., 1995, 'Namhangwa Bughan-ui tong-ilgwa huinyeon-eul wihan sahoeyunlijeog jeobgeun', Korea Journal of Christian Studies 12(1), 172-203.

Park, M.G., 2000, 'Hangugjeonjaeng-gwa minjogjuui', Aseamunhwa, Je 16ho, Han-lim University Asia munhwa yeongu-so, Chun-Chun.

Repschinski, B., 2000, The controversy stories in the Gospel of Matthew: Their redaction, form and for the relationship between the Matthean Community and Formative Judaism, Vandenhock \& Ruprecht, Göttingen.

Saldarini, A.J., 1994, Matthew's Christian-Jewish community, University of Chicago, Chicago, IL.

Shin, I.C., 2004, 'Matthew's inclusive community: A narratological and social scientific reading', Unpublished PhD theses, University of Pretoria, Pretoria.

Shin, I.C., 2012, 'Yesooeui pyeonghwa-sasang (Pacifism) gareuchime hameuiden mataegongdongchewa yoodaekyoueui bun-ri jeonghwang', Bog-eumgwa Silcheon 50, 91-117.

Shin, I.C., 2019, 'The Matthean Community's state of coexistence between Jews and Gentiles', HTS Theologiese Studies/Theological Studies 75(4), a5531. https://doi. org/10.4102/hts.v75i4.5531.

Shin, I.C. \& Van Aarde, A.G., 2005, 'Matthew's and Paul's inclusive tendencies: A comparison', HTS Theologiese Studies/Theological Studies 61(4), 1353-1372. https://doi.org/10.4102/hts.v61i4.488

Shin, J.D., 2014, 'Nambukkwangyesaeui bunsuk soojoonkwa juyo uije', Hangukgwa Kukje jeongchi 30(3), 155-196.

Sim, D.C., 1998, The Gospel of Matthew and Christian Judaism: The history and social setting of the Matthean community, T \& T Clark, Edinburgh.

Sim, D.C., 2011, 'The pacifist of Jesus and the violent Jesus in the Gospel of Matthew', HTS Theologiese Studies/ Theological Studies 67(1), Art. \#860, 1-6.https://doi. org/10.4102/hts.v67i1.860

Song, Y.S., 2012, 'Nambughan tonghab-eul wihan 'hwahaedoen minjog dongjilseong' e daehan non-ui', Gaehyeog Nonchong 21, 45-70.

Stanton, G.N., 1992, A Gospel for a new people: Studies in Matthew, T \& T Clark, Edinburgh.

Talbert, C.H., 2010, Matthew, Baker Academic, Grand Rapids, MI. (PCNT).

Thiessin, M., 2012, 'Abolishers of the Law in early Judaism and Matthew 5:17-20', Biblica, 93(4), 543-556.

Viljoen, F.P., 2014, 'Jesus healing the leper and the purity Law in the Gospel of Matthew', In die Skrifing 48(2), Art. \#1751, 1-7. https://doi.org/10.4102/ids. v48i2.1751

Volf, M., 2000a, 'The final reconciliation: Reflections on a social dimension of the eschatological tradition', Modern Theology 16(1), 91-113. https://doi. org/10.1111/1468-0025.00117

Volf, M., 2000b, 'The social meaning of reconciliation', Interpretation- Journal of Biblical and Theology 54(2), 158-172. https://doi.org/10.1177/002096430005400205

Woo, T.J., 2018, 'Tongildamroneul wuihan guyakseongseoui jeaan', Bogeumgwa SilCheon 62(Fall), 16-20. 